\title{
Emulsifying properties of defatted rice bran concentrates enriched in fiber and proteins.
}

Carla Bonifacino ${ }^{\mathrm{a}^{*}}$, Eugenia Franco Fraguas ${ }^{\mathrm{a}}$, Débora N. López,c, Jorge R. Wagner ${ }^{\mathrm{d}}$, Darío M. Cabezas $^{\mathrm{d}}$, Luis A. Panizzolo ${ }^{\mathrm{a}}$, Gonzalo G. Palazolo ${ }^{\mathrm{d}}$, Cecilia Abirached ${ }^{\mathrm{a}}$

a Laboratorio de propiedades funcionales de Alimentos, Departamento de Ciencia y Tecnología de los Alimentos, Facultad de Química, Universidad de la República, Av. Gral. Flores 2124, Montevideo, Uruguay.

• Área Fisicoquímica, Departamento de Química Física. Facultad de Ciencias Bioquímicas y Farmacéuticas, Universidad Nacional de Rosario- CONICET. Suipacha 531, Rosario, Argentina.

c Facultad de Química e Ingeniería del Rosario, Pontificia Universidad Católica Argentina. Av. Pellegrini 3314, Rosario, Argentina.

${ }^{d}$ Laboratorio de Investigación en Funcionalidad y Tecnología de Alimentos, Departamento de Ciencia y Tecnología, Universidad Nacional de Quilmes, CONICET, Roque Sáenz Peña 352, B1876BXD, Bernal, Argentina.

* Corresponding author Lic. Bonifacino Carla

Tel: (+598) 29242675

E-mail address: cbonifacino@fq.edu.uy

ORCID: 0000-0001-7798-9978

This article has been accepted for publication and undergone full peer review but has not been through the copyediting, typesetting, pagination and proofreading process which may lead to differences between this version and the Version of Record. Please cite this article as doi: $10.1002 /$ jsfa. 10150 


\begin{abstract}
BACKGROUND: Rice bran (RB), a by-product of rice milling industry, constitutes around $10 \%$ of the total weight of rough rice. The interest in the use of RB is centered on its nutritional quality, its low cost and its worldwide extensive production. As RB is commonly used for oil extraction, the defatted rice bran (DRB) is obtained as a second by-product. The aim of this work was to obtain a defatted rice bran concentrate (DRBC), enriched in protein and fiber, from defatted rice bran flour (DRBF) and to determine its physicochemical and emulsifying properties.
\end{abstract}

RESULTS: To obtain the DRBC, the starch was efficiently hydrolyzed (> 98\%) with $\alpha$ amylase and amyloglucosidase, with the concomitant increase of crude protein (from 154.7 to $274.3 \mathrm{~g} \mathrm{~kg}^{-1}$ ) and total dietary fiber (from 276.1 to $492.3 \mathrm{~g} \mathrm{~kg}^{-1}$ ) proportions. DRBC exhibited a loss of protein solubility and increased surface hydrophobicity compared with DRBF. DRBC dispersions with and without previous ultrasound treatment were prepared. The sonication led to an increase in the apparent viscosity. Emulsions were prepared with dispersions with and without previous ultrasound treatment and showed high stability in quiescent conditions during 28 days. However, the emulsions prepared with dispersions treated with ultrasound resulted in lower $\mathrm{D}_{4,3}$ values and higher elastic and viscous moduli.

CONCLUSION: The rice bran concentrate can be used to obtain stable $\mathrm{O} / \mathrm{W}$ emulsions, including both fractions, soluble and insoluble, in acidic and neutral conditions. Thus, these innovative findings contribute to increase the added value of this important by-product of ricemilling industry.

KEYWORDS: Oryza sativa; industrial by-product; fiber and protein concentrates; O/W emulsions. 


\section{Introduction}

Rice (Oryza sativa) is the staple food for more than half of the population and is therefore one of the most produced cereals in the world. ${ }^{1}$ As it is mainly consumed white, rice bran (RB) is obtained as a by-product in the rice milling process, ${ }^{2}$ representing $10 \%$ of the grain weight. ${ }^{3}$

The interest in the use of RB for food elaboration is centered on its nutritional quality, its low cost as well as its worldwide extensive production. Rice bran proteins, which represent 11$16 \%$ of the RB total weight,, ${ }^{4,5}$ have a higher nutritional quality than other vegetable proteins. ${ }^{6}$ These proteins are easily digested (>90\%), hypoallergenic and present anticancer activity. ${ }^{7}$ The total dietary fiber content represents $27-33 \%$ of the RB total weight, where $94 \%$ corresponds to insoluble dietary fiber and $6 \%$ to soluble dietary fiber. The insoluble dietary fiber is mainly composed of 33\% cellulose, 55\% hemicellulose and 6\% lignin., ${ }^{2,8}$

As RB is commonly used for oil extraction, the defatted rice bran (DRB) is obtained as a second by-product. ${ }^{7}$ Because of the oil removal, there is a change in the relative amount of nutrients of DRB, leading to higher contents of crude protein, ash, total dietary fiber, as well as higher availability of $\mathrm{Ca}$ and $\mathrm{Fe}$ and higher protein digestibility. ${ }^{9}$ Prior to oil extraction, a heat stabilization process of rice bran is necessary to inhibit oil deterioration by enzymatic inactivation. This treatment usually leads to protein denaturation and enhances the linkages among proteins and carbohydrates or other components making more difficult the protein extraction. ${ }^{10-12}$ The loss of protein solubility due to protein denaturation during heat stabilization was reported earlier by other authors. ${ }^{13,14}$

Various enzymatic chemical and physical methods have been used for the extraction and concentration of proteins and dietary fiber. ${ }^{15,16}$ The main advantage of enzymatic methods is the fact that proteins are not exposed to alkaline conditions avoiding not only the formation of undesirable substances, but also the loss of nutritional characteristics. ${ }^{17}$ 
The use of proteins and polysaccharides from vegetable sources as ingredients in foods gives them an added value at low cost of production. ${ }^{2}$ These components possess functional properties that provide desirable attributes to the food products. In general, proteins and polysaccharides are added as stabilizers, emulsifiers, thickeners and texture improving agents. ${ }^{18}$

The emulsification is related to the surface-active behavior of the components and hence, it is important to the formulation of traditional and novel food emulsions. ${ }^{19}$

In this regard, the addition of polysaccharides in foods is usually limited by their physical and chemical characteristics, which reinforces the need to apply treatments that allow their use, such as the reduction of particle size by ultrasound treatments. ${ }^{15}$ Proteins are used as emulsifiers due to their ability to prevent droplet aggregation and coalescence, ${ }^{20}$ whereas, only polysaccharides with sufficient hydrophobic characteristics or those that are linked to proteins enable the formation of stable emulsions by adsorbing them at the oil/water interface. Hence, polysaccharides are usually incorporated to emulsions to stabilize the droplets by increasing the viscosity of the continuous phase. ${ }^{21}$

The studies concerning with the assessment of the emulsifying functional properties of rice bran protein isolates or soluble protein concentrates have been addressed ${ }^{22-25}$ but none of these has considered to evaluate the impact of the presence of fiber on the aforementioned properties.

On the basis of above considerations, the aim of this work was to obtain a defatted rice bran concentrate (DRBC), enriched in protein and fiber, from defatted rice bran flour (DRBF) and to determine its physicochemical and emulsifying properties allowing a better use of this byproduct. 
2. Materials and methods

\subsection{Materials}

2.2. The DRB from the variety EI Paso 144 used in this study was donated by a company that produces rice bran oil. a-amylase (from Bacillus lincheniformis, EC 3.2.1.1, 11,350 units $\mathrm{mL}^{-1}$ ), amyloglucosidase (from Aspergillus niger, EC 3.2.1.3, 237.7 units $\mathrm{mL}^{-1}$ ), bicinchoninic acid (BCA) and 1-anilino-8 naphthalenesulfonic acid (ANS) were purchased from Sigma-Aldrich (St. Louis, MO). Bovine serum albumin (BSA) was purchased from GIBCO BRL (Germany). All chemicals used were of analytical grade.Preparation of DRBF and DRBC samples

Firstly, the defatted rice bran flour (DRBF) was obtained by sieving the defatted rice bran (DRB) (0.355 mm ASTM). To obtain the defatted rice bran concentrate (DRBC), the starch was enzymatically hydrolyzed. ${ }^{26}$ DRBF was dispersed in distilled water $\left(100 \mathrm{~g} \mathrm{~L}^{-1}\right)$ for $1 \mathrm{~h}$ under magnetic stirring at room temperature. The $\mathrm{pH}$ was adjusted to 5.5 with $2.0 \mathrm{~mol} \mathrm{~L}^{-1} \mathrm{HCl}$ solution and a treatment with $\alpha$-amylase at $1 \mathrm{~mL} \mathrm{~L}^{-1}$ was performed for $60 \mathrm{~min}$ at $95{ }^{\circ} \mathrm{C}$. Upon cooling to room temperature, $\mathrm{pH}$ was adjusted to 4.5 with $2.0 \mathrm{~mol} \mathrm{~L}^{-1} \mathrm{HCl}$ solution. The dispersion was subsequently incubated with $10 \mathrm{~mL} \mathrm{~L}^{-1}$ amyloglucosidase for $30 \mathrm{~min}$ at $60{ }^{\circ} \mathrm{C}$. The precipitation of the fiber and water-soluble proteins was carried out with the addition of 710 $\mathrm{mL} \mathrm{L} \mathrm{L}^{-1}$ ethanol for $24 \mathrm{~h}$. After the centrifugation of the resulting dispersion $(10,000 \times \mathrm{g}, 20 \mathrm{~min}$, $20{ }^{\circ} \mathrm{C}$ ) the supernatant, which was mainly enriched in simple sugars and minerals, was discarded. The precipitate was recovered and washed with $950 \mathrm{~mL} \mathrm{~L}^{-1}$ ethanol-distilled water at ratio of 3:1, to eliminate the simple sugars. The precipitate was dried at $40{ }^{\circ} \mathrm{C}$ to remove ethanol and subsequently dispersed in distilled water $\left(100 \mathrm{~g} \mathrm{~L}^{-1}\right)$ adjusting the $\mathrm{pH}$ to 8.0 with $2.0 \mathrm{~mol} \mathrm{~L}^{-1}$ 
$\mathrm{NaOH}$ solution. The resultant aqueous dispersion was lyophilized (Biobase BK-FD10S, China) to obtain the DRBC. Recovery yield was calculated as gram of DRBC per kg of DRBF. Moreover, to determine the recovery yield of the soluble and insoluble fractions of DRBC, the aqueous dispersion was centrifuged $\left(10,000 \times \mathrm{g}, 40 \mathrm{~min}, 20{ }^{\circ} \mathrm{C}\right)$. The soluble fraction (supernatant) and insoluble fraction (pellet) were then lyophilized and the recovery yields were calculated as gram of soluble DRBC per kg of DRBC and gram of insoluble DRBC per kg of DRBC respectively.

\subsection{Proximate composition}

The proximate composition of DRBF and DRBC was determined following standard methods ${ }^{27}$ : crude protein content by the Kjeldahl method $(\mathrm{N} \times 5.95)^{28}$, total dietary fiber (soluble + insoluble) according to Prosky method, lipids by Soxhlet extraction with hexane as solvent, moisture content by oven drying at normal pressure $\left(105 \pm 2{ }^{\circ} \mathrm{C}\right)$, and total ash by dry-ashing at $550 \pm 10{ }^{\circ} \mathrm{C}$. Carbohydrates (non-fiber) content was determined by difference. The removal efficiency of non-fiber carbohydrates was expressed as the percentage of the non-fiber carbohydrates in the DRBC respect to DRBF.

\subsection{Differential Scanning Calorimetry (DSC)}

The peak temperature $\left(\mathrm{Tp},{ }^{\circ} \mathrm{C}\right)$ of the endothermic peaks and specific and total enthalpy $\left(\Delta \mathrm{H}, \mathrm{J} \mathrm{g} \mathrm{g}^{-1}\right.$ dry matter) of DRBF and DRBC dispersions were obtained from thermograms analysis and determined using a calorimeter (DSC Q200 TA Instruments, LLC Waters, United States). Aqueous dispersions of DRBF and DRBC were prepared in distilled water at 250 and $200 \mathrm{~g} \mathrm{~L}^{-1}$ respectively. Approximately $12 \mathrm{mg}$ of sample were placed in standard hermetic aluminum pans. An empty aluminum pan was used as reference. The thermograms were obtained at a heating rate of $5{ }^{\circ} \mathrm{C} \min ^{-1}$ in the range of $10-130{ }^{\circ} \mathrm{C} \cdot{ }^{28,29}$ The $\mathrm{Tp}$ and $\Delta \mathrm{H}$ were 
obtained from the analysis of thermograms with the Universal Analysis 2000 software (TA Instruments, LLC Waters, United States).

\subsection{Protein solubility (PS)}

DRBF and DRBC samples were dispersed $\left(10.0 \mathrm{~g} \mathrm{~L}^{-1}\right)$ in $10.0 \mathrm{mmol} \mathrm{L}^{-1}$ citrate phosphate buffer (CPB) at $\mathrm{pH} 4.5$, which is reported as the isoelectric point $(\mathrm{pI})$ of isolated rice bran proteins, or $\mathrm{pH} 7.0 .^{22}$ The dispersions were kept under stirring for $60 \mathrm{~min}$ at room temperature, and finally centrifuged $\left(10,000 \times \mathrm{g}, 10 \mathrm{~min}, 20^{\circ} \mathrm{C}\right)$. The protein content in the supernatant was determined by the BCA method using a commercial kit (B9643; Sigma-Aldrich, MO, United States). ${ }^{30}$ BSA was used as standard protein. The absorbance was read at $560 \mathrm{~nm}$ in a microplate reader (Thermo Scientific ${ }^{\mathrm{TM}}$ Multiskan $^{\mathrm{TM}}$ FC, Finland). The PS was calculated as gram of soluble protein per kg of the total protein. Total protein content was determined by Kjeldahl $(\mathrm{N} \times 5.95)$.

\subsection{Surface hydrophobicity $\left(\mathrm{H}_{0}\right)$}

Aromatic surface hydrophobicity was determined on soluble protein fraction of samples prepared as detailed in section 2.5, according to Fernández-Fernández et al. ${ }^{31}$ based on fluorescence measurements with the ANS probe in a spectrofluorometer (Infinite M200 PRO Tecan Group Ltd., Switzerland). The protein concentration in the supernatant was determined by the BCA method (section 2.5).

\subsection{Determination of $\zeta$-potential}

Samples of DRBF and DRBC were dispersed in distilled water $\left(0.5 \mathrm{~g} \mathrm{~L}^{-1}\right)$ and centrifuged $\left(10,000 \times \mathrm{g}, 10 \mathrm{~min}, 20^{\circ} \mathrm{C}\right)$ in order to determine $\zeta$-potential of the soluble fraction. The $\mathrm{pH}$ of these samples was adjusted in the range 2.0-10.0 with $0.1 \mathrm{~mol} \mathrm{~L}^{-1} \mathrm{HCl}$ or $\mathrm{NaOH}$ solutions; the dispersions were kept under magnetic stirring for $1 \mathrm{~h}$ at room temperature. The $\zeta$-potential was 
determined from its electrophoretic mobility, using a nano-particle analyzer (Horiba SZ-100, Horiba Ltd., Japan).

\subsection{Preparation of DRBC aqueous dispersions}

Aqueous dispersions ( $4.0 \mathrm{~g} \mathrm{~L}^{-1}$ of soluble protein) were prepared in $\mathrm{CPB}$ at $\mathrm{pH} 4.5$ or 7.0 by magnetic stirring for $1 \mathrm{~h}$ at room temperature, and were denominated $\boldsymbol{d}_{4.5}$ and $\boldsymbol{d}_{7.0}$. The sample concentration was previously determined to be optimal to form a stable emulsion (data not shown). Sodium azide $\left(0.2 \mathrm{~g} \mathrm{~L}^{-1}\right)$ was added to retard the microbial growth. Other dispersions,

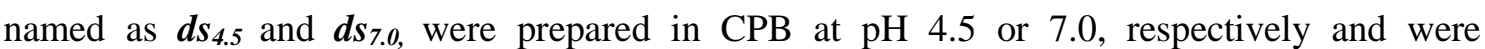
homogenized by ultrasound treatment (Sonic Vibra Cell VCX750, Sonics \& Materials Inc., United States) in a $50 \mathrm{~mm}$ diameter glass beaker. For this, a 2-min cycle was applied with on: off sequences of 15 and $20 \mathrm{~s}, 20 \mathrm{kHz}$, at a power level of $70 \%$ and a total power delivered of 58 W. Temperature was controlled $\left(<35^{\circ} \mathrm{C}\right)$ using a water-ice bath.

\subsection{Flow behavior of aqueous dispersions}

Flow behavior of the dispersions was evaluated using a rheometer (Anton Paar Physica 301, Anton Paar, Austria) equipped with a concentric cylinder geometry (DG26.7/1). The flow curves (shear stress, $\tau$ vs. shear rate, $\gamma$ ) were performed at $24{ }^{\circ} \mathrm{C}$. The shear rate was firstly increased from 1 to $200 \mathrm{~s}^{-1}$ and finally decreased from 200 to $1 \mathrm{~s}^{-1}$.

\subsection{Preparation of $\mathrm{O} / \mathrm{W}$ emulsions}

Emulsions were prepared with the DRBC dispersions as continuous phase, and refined sunflower oil as dispersed phase (oil mass fraction, $\phi_{\mathrm{m}}=0.25$ ). Emulsions prepared with $\boldsymbol{d}_{4.5}$, $\boldsymbol{d}_{7.0}, \boldsymbol{d} s_{4.5}$ and $\boldsymbol{d} s_{7.0}$ were named as $\boldsymbol{e} \mathbf{I}_{4.5}, \boldsymbol{e I _ { 7 . 0 }}, \boldsymbol{e I I} \mathbf{I}_{4.5}$ and $\boldsymbol{e I I} \mathbf{I}_{7.0}$, respectively. In all cases, a preemulsion was prepared by high-speed homogenization (Ultraturrax T-25, S 25 N-10 G 
dispersion tool, IKA Labortechnik, Germany) at 20,000 rpm for 2 min. Subsequently, this preemulsion was homogenized by ultrasound as detailed for the dispersion in section 2.8 .

\subsection{Evaluation of DRBC emulsifying properties}

\subsubsection{Optical characterization}

The destabilization process of the emulsions in quiescent conditions was analyzed from their backscattering (\%BS) profiles during 28 days at $24 \pm 2{ }^{\circ} \mathrm{C} .{ }^{32}$ The \%BS was measured using a vertical scan analyzer (TurbiScan Classic MA 2000, Formulaction, France), according to multiple light scattering theory. ${ }^{33}$ The stability against creaming was evaluated from the variation of BS profiles as a function of storage time. ${ }^{34,35}$ Average \%BS values in the lower zone of the tube (at a height of $10 \mathrm{~mm}$ ) were calculated using the TurbiSoft ${ }^{\circledR} \mathrm{v}$ 1.2.1 software (Formulation, France).

\subsubsection{Particle size distribution}

Particle size distribution (PSD) of the emulsions at the beginning and the end of the quiescent storage was determined using a particle size analyzer (Coulter LS 230, Beckman Coulter Inc., United States) with Fraunhofer optical model, and was expressed as volume (\%). From PSD, the De Brouckere, volume-weighted, mean diameter $\left(\mathrm{D}_{4,3}\right)$ was obtained.

\subsubsection{Rheological behavior of emulsions}

On freshly-made emulsions, a frequency sweep test was performed at $24{ }^{\circ} \mathrm{C}$ using a rheometer (Anton Paar Physica 301, Anton Paar, Austria) associated to a parallel-plate geometry (PP25/TG, gap $1000 \mu \mathrm{m}$, diameter $25 \mathrm{~mm}$ ). The experimental data were obtained by recording the storage or elastic modulus ( $\left.G^{\prime}\right)$ and the loss or viscous modulus ( $\left.G "\right)$ as a function of the oscillation frequency $(0.1-20.0 \mathrm{~Hz})$ within the range of linear viscoelasticity, previously determined by stress sweep tests $($ strain $=1.0 \%)$. 


\subsection{Statistical analysis}

All determinations were made in triplicate. Results were expressed as mean values \pm standard deviation. Significant differences among mean values $(\mathrm{P}<0.05)$ were determined by means of the analysis of variance (ANOVA) and the Tukey test (Infostat v. 2015, Universidad Nacional de Córdoba, Argentina).

\section{Results and discussion}

\subsection{Characterization of DRBF and DRBC samples}

\subsubsection{Recovery yield and proximate composition}

The removal efficiency of non-fiber carbohydrates by the action of the $\alpha$-amylase and amyloglucosidase enzymes on the starch was greater than 98\% (Table 1). A previous study has reported a removal efficiency of $75 \%$ applying only the $\alpha$-amylase treatment, ${ }^{36}$ suggesting that the combination of hydrolysis with $\alpha$-amylase and amyloglucosidase is a more suitable strategy for starch removal from DRBF. Moreover, the removal of non-fiber carbohydrates enhanced the crude protein, ash and total dietary fiber proportions in DRBC when compared to DRBF (P < 0.05). Conversely, the fat content of both samples was similar $(\mathrm{P}>0.05$, Table 1$)$. The recovery yield of DRBC was $560.9 \pm 26.7 \mathrm{~g} \mathrm{~kg}^{-1}$ of DRBF. The soluble and insoluble fractions recovery yield in the DRBC was $90.2 \pm 3.1 \mathrm{~g} \mathrm{~kg}^{-1}$ and $909.8 \pm 22.4 \mathrm{~g} \mathrm{~kg}^{-1}$ respectively.

\section{Table 1}

\subsubsection{Differential scanning calorimetry}

The DSC tests showed that DRBF had two endothermic peaks, one at $70.0 \pm 1.3^{\circ} \mathrm{C}$, that would correspond to the gelatinization of the native starch, ${ }^{37}$ and the second one at $91.9 \pm 1.0$ ${ }^{\circ} \mathrm{C}$, which could probably be attributed to protein denaturation. ${ }^{28}$ This sample showed a total enthalpy of $2.2 \pm 0.2 \mathrm{~J} \mathrm{~g}^{-1}$ (dry basis), and a $\Delta \mathrm{H}$ associated to the protein denaturation of $0.49 \pm$ $0.01 \mathrm{~J} \mathrm{~g}^{-1}$ (dry basis). The DRBC sample did not show any endothermic transitions, suggesting 
the absence of starch removed by the action of amylases, as well as the presence of fully denatured proteins. Unlike DRBF, DRBC showed an exothermic transition at an initial temperature of $61.2 \pm 4.2^{\circ} \mathrm{C}$ and a Tp at $83.1 \pm 1.1^{\circ} \mathrm{C}$ (Fig. 1). This fact could be associated to an aggregation process of the previously denatured proteins caused by the release of energy in structure formation with an associated enthalpy of $17.6 \pm 0.7 \mathrm{~J} \mathrm{~g}^{-1}$ (dry basis). ${ }^{29}$

\section{Figure 1}

\subsubsection{Protein solubility, surface hydrophobicity and $\zeta$-potential}

DRBC exhibited a noticeable loss of PS, which is probably associated to heating and ethanol treatments necessary to obtain the concentrate (Table 2). In fact, protein denaturation was confirmed by DSC as mentioned above (Fig. 1). These treatments would favor proteinprotein interactions promoting aggregation and precipitation via hydrophobic interactions with the concomitant loss of solubility. ${ }^{38}$

In addition, $\mathrm{H}_{0}$ was higher in DRBC than in DRBF at both $\mathrm{pH}(\mathrm{P}<0.05$, Table 2$)$. Hydrophobic amino acids tend to be located in the core of the structure in native proteins in order to avoid their exposure to the hydrophilic environment, a situation that is thermodynamically unfavorable. ${ }^{39}$ For DRBC, the protein denaturation induced by the extraction procedure increased the surface exposure of these hydrophobic residues which led to a higher $\mathrm{H}_{0}$ and a lower PS. ${ }^{40}$ The PS of DRBC at pH 7.0 was slight, but significantly lower than that at $\mathrm{pH} 4.5(\mathrm{P}<0.05)$, suggesting that the surface exposure of the hydrophobic residues is higher at $\mathrm{pH}$ 7.0.

Moreover, for DRBF and DRBC samples, the $\zeta$-potential of the soluble fraction was measured, obtaining a pI value of 3.0 without significant differences between them $(\mathrm{P}>0.05)$. Although the reported pI in the literature is 4.5 for isolated rice bran proteins ${ }^{22}$, it should be noticed that in this study, the defatted rice bran used was subjected to a heat stabilization 
process, and it is well known that it induces protein denaturation with the concomitant change of pI. Studies by Xia et al. using rice bran protein isolate prepared from heat-stabilized rice bran reported a pI value of $3.5 .{ }^{10}$ Another study carried out on the soluble fraction of protein hydrolysates of rice bran reported pI values between 2 and 3, and suggests that the presence of charged carbohydrates in the samples could influence the $\zeta$-potential. ${ }^{41}$

Above $\mathrm{pH}$ 3.0, negative $\zeta$-potential values were obtained for both samples, but they increased with increasing $\mathrm{pH}$ only for DRBC (Table 2), presumably due to the electrostatic repulsion between protein molecules and charged carbohydrates.

Although the DRBC exhibited more negative $\zeta$-potential values than those of DRBF, the PS of DRBC was noticeably lower (Table 2). In this regard, the attractive hydrophobic interactions have a key role in promoting the loss of PS. This observation was supported by the higher $\mathrm{H}_{0}$ for $\mathrm{DRBC}$, as was mentioned above.

\section{Table 2}

\subsection{Characterization of dispersions}

\subsubsection{Rheological properties of dispersions}

Firstly, the flow behavior of the dispersions, used as continuous phase in the preparation of emulsions, was analyzed (Fig. 2A and B). All the dispersions behaved as pseudoplastic fluids and the hysteresis was also consistent with a thixotropic behavior. ${ }^{42}$ This flow behavior is characteristic of dispersions that contain particles of biopolymers aggregated by weak forces. ${ }^{43}$ The shear treatment causes the aggregated particles to deform and break progressively, which decreases the resistance to flow and, therefore, causes a reduction in viscosity over time. ${ }^{42}$

It was also observed that dispersion prepared at $\mathrm{pH} 7.0$ had a higher viscosity that dispersion prepared at $\mathrm{pH} 4.5(\mathrm{P}<0.05)$. Due to the lower PS of DRBC at $\mathrm{pH} 7.0$, it was necessary to weight a higher amount of DRBC at $\mathrm{pH} 7.0$ than at $\mathrm{pH} 4.5$, to obtain the same 
soluble protein content $\left(4.0 \mathrm{~g} \mathrm{~L}^{-1}\right)$ at both $\mathrm{pH}$. Thus, the increase of total solids in the dispersions, which was in agreement with an increase of polysaccharides and insoluble protein, affected their flow behavior. ${ }^{44,45}$ It was also observed that the sonicated dispersions had higher viscosity values than the untreated ones. This result would be consistent with a decrease of size of insoluble particles induced by the sonication, which would promote a higher molecular entanglement.

\section{Figure 2}

\subsection{Emulsifying properties of DRBC}

\subsubsection{Optical characterization}

The \%BS profiles and average values showed constant BS values along the entire tube during 28 days of quiescent storage, without significant differences $(\mathrm{P}>0.05)$ for all emulsions. The $\boldsymbol{e I}$ emulsions presented lower values of BS than the $\boldsymbol{e I I}$ ones at both $\mathrm{pH}$ in the lower zone of the tube $(10 \mathrm{~mm})$ (Fig. $3, \mathrm{P}<0.05)$. The $\mathrm{BS}$ variation against time allows to discriminate between processes of particle migration (sedimentation and creaming) and variation of particle size due to flocculation and coalescence. ${ }^{32}$ No changes were observed both in the $\% \mathrm{BS}$ profiles and \%BS average values, so that the emulsions were stable against creaming and coalescence. Porfiri et al., working with insoluble polysaccharides fractions obtained from soybean, reported similar BS values for emulsions prepared under similar conditions. ${ }^{20}$

\section{Figure 3}

\subsubsection{Particle size analysis}

The comparative analysis of the particle size of emulsions was assessed. In all cases, the PSD were multimodal, with particle populations in the range from 3.0 to $220.0 \mu \mathrm{m}$. A similar behavior was reported by Leiva and Geffroy. ${ }^{46}$ Emulsions prepared with sonicated dispersions 
$\left(\boldsymbol{e I I} \mathbf{I}_{.5}\right.$ and $\left.\boldsymbol{e I I} \boldsymbol{I}_{7.0}\right)$ showed significantly lower $\mathrm{D}_{4,3}$ values $(\mathrm{P}<0.05)$ than those prepared with the dispersions, without any previous treatment ( $\boldsymbol{e I}_{4.5}$ and $\left.\boldsymbol{e I}_{7.0}\right)$ (Fig. 4A and B).

\section{Figure 4}

Due to the complexity in the composition of the DRBC, the observed decrease in $\mathrm{D}_{4,3}$ caused by the previous ultrasound treatment on the dispersions may be a combination of at least two factors that are not independent: first, the particle disintegration of the polysaccharides ${ }^{15}$ and insoluble proteins, and second, the more efficient interfacial adsorption during the emulsification process as well as the formation of smaller droplets. Reducing the particle size would increases the surface area and would allow more surface interaction with oil. ${ }^{2,20}$ Nevertheless, after quiescent storage (28 days), the $\mathrm{D}_{4,3}$ of all emulsions was similar respect to that of freshly-made ones ( $\mathrm{P}>0.05$, Fig. 4), indicating that emulsions were stables regardless of the previous sonication of the dispersions. These results were consistent with those obtained using the vertical scan analyzer (Fig. 3).

\subsubsection{Rheological properties of emulsions}

The frequency sweep tests, for all cases, showed that the storage modulus was larger than the loss modulus ( $\left.G^{\prime}>G^{\prime \prime}\right)$ maintaining this behavior throughout the frequency range (Fig. 5). This observation indicates the formation of a strong gel-like material, which is directly related to the presence of hydrated flocs in all emulsions, confirmed by optical microscopy at the beginning of storage (data not shown). ${ }^{47}$ At both $\mathrm{pH}$, this rheological behavior was enhanced in the emulsions prepared with sonicated dispersions due to the greater interaction between droplets of smaller size (Fig. 4). However, G’ values were higher for emulsions prepared with dispersions obtained with and without ultrasound treatment a pH $7.0\left(\boldsymbol{e I}_{7.0}\right.$ and $\left.\boldsymbol{e I I} \mathbf{I}_{7.0}\right)$, which would be in agreement with the increase of the amount of insoluble proteins and polysaccharides, being these articles capable of interacting closely with the droplet. Therefore, 
for all emulsions, the rheological behavior depends on the concentration of polysaccharides and the physical treatment applied to the dispersion, indicating a behavior with elastic rather than viscous characteristics in all samples and the gradual increase in stiffness. ${ }^{48}$ Moreover, although the emulsions were initially flocculated and the droplets were close together during storage, the presence of insoluble protein and polysaccharides would avoid the coalescence of the droplets by forming an effective steric barrier around the droplets ${ }^{49}$ and lowering the mobility of the system. ${ }^{20}$

\section{Figure 5}

\section{Conclusions}

Concentrates rich in dietary fiber and proteins were obtained from a waste of the rice industry with a promising use as a food ingredient, increasing the added value of this important by-product. The high content of insoluble fraction observed in the DRBC highlights the importance of using the whole concentrate for the preparation of functional foods. Moreover, the low non-fiber carbohydrates content in the concentrate ensures the development of lowcalories food products. The high stability of the emulsions in quiescent conditions may be due to the effective steric barrier generated by the presence of fiber carbohydrates in the concentrates, which could decrease the frequency of collision between the drops by increasing the viscosity of the continuous phase and/or by its interfacial activity associated to proteins. Emulsions treated with ultrasound enabled a greater disintegration and/or a decrease in the size of the polysaccharides leading to a better rearrangement of the oil droplets, which resulted in an increase of the apparent viscosity of the continuous phase as well as higher elastic and viscous moduli of the emulsion. The innovative findings of this study demonstrated that the DRBC could be used to prepare highly stable $\mathrm{O} / \mathrm{W}$ emulsions both in acidic and neutral conditions. Considering that DRBC showed an aggregation process at $83{ }^{\circ} \mathrm{C}$, this concentrate would be 
suitable for food product formulations that do not require heat treatments at temperatures higher than $83^{\circ} \mathrm{C}$.

\section{Acknowledgements}

The research was supported by the Agencia Nacional de Investigación e Innovación by the PhD scholarship POS_FCE_ 2015_1_1005331 and the FCE_1_2014_1_104768 research project, Programa de Desarrollo de las Ciencias Básicas (PEDECIBA-UDELAR) and Comisión Sectorial de Investigación Científica Iniciación 1815/2017 (Resp. C. Bonifacino) project. The authors would like to thank to Antonio Malanga, Laboratorio Biofarmacia y Tecnología Farmacéutica, Facultad de Química-UdelaR and Eliana Budelli, Instituto de Ingeniería Química, Facultad de Ingeniería-UdelaR.

\section{References}

1 Wang X, Chen H, Fu X, Li S, Wei J. A novel antioxidant and ACE inhibitory peptide from rice bran protein: Biochemical characterization and molecular docking study. LWT - Food Sci. Technol. 75:93-9 (2017).

2 Wang J, Suo G, De Wit M, Boom RM, Schutyser MAI. Dietary fibre enrichment from defatted rice bran by dry fractionation. J. Food Eng. 186:50-7 (2016).

3 Phongthai S, Homthawornchoo W, Rawdkuen S. Preparation, properties and application of rice bran protein: A review. Int. Food Res. J 24(1):25-34 (2017).

4 Gopinger E, Ziegler V, Catalan AA da S, Krabbe EL, Elias MC, Xavier EG. Whole rice bran stabilization using a short chain organic acid mixture. J. Stored Prod. Res. 61:10813 (2015).

5 Gul K, Yousuf B, Singh AK, Singh P, Wani AA. Rice bran: Nutritional values and its emerging potential for development of functional food - A review. Bioact. 
Carbohydrates Diet Fibre 6(1):24-30 (2015).

6 Han SW, Chee KM, Cho SJ. Nutritional quality of rice bran protein in comparison to animal and vegetable protein. Food Chem 172:766-9 (2015). Yousif EI, Kishk YFM, Elsheshetawy HE, El-makarem MAA. Functional and nutritional characteristics of prepared rice bran protein products. World J. Dairy Food Sci. 11(1):100-8 (2016).

8 Wen Y, Niu M, Zhang B, Zhao S, Xiong S. Structural characteristics and functional properties of rice bran dietary fiber modified by enzymatic and enzyme-micronization treatments. LWT - Food Sci. Technol. 75:344-51 (2017).

9 Kumari N, Vinita NK, Rani P. Nutrient composition of full fat and defatted rice bran. Asian J. Dairy Food Res. 37(1):77-80 (2018).

10 Xia, N., Wang, J., Yang, X., Yin, S., Qi, J., Hu, L., Zhou, X. Preparation and characterization of protein from heat-stabilized rice bran using hydrothermal cooking combined with amylase pretreatment. J. Food Eng. 110(1):95-101 (2012).

11 Tang, S., Hettiarachchy, NS., Eswaranandam, S., Crandall, P. Protein extraction from heat-stabilized defatted rice bran: II. The role of amylase, celluclast, and viscozyme. $J$. Food Sci. 68(2):471-75 (2003).

12 Tang, S., Hettiarachchy, NS., Shellhammer, TH. Protein extraction from heat-stabilized defatted rice bran. 1. Physical processing and enzyme treatments. J. Agric. Food Chem. 50(25):7444-48 (2002).

13 Sharma, HR., Chauhan, GS., Agrawal, K. Physico-chemical characteristics of rice bran processed by dry heating and extrusion cooking. Int. J. Food Prop. 7(3):603-614 (2004).

14 Rafe, A., Sadeghian, A., Hoseini-Yazdi, SZ. Physicochemical, functional, and nutritional characteristics of stabilized rice bran form tarom cultivar. Food Sci. Nutr. 5(3):407-14 
(2016).

15 Ogutu FO, Mu T-H, Elahi R, Zhang M, Sun H-N. Ultrasonic modification of selected Polysaccharides-Review. J. Food Process Technol. 6(5);446 (2015).

Phongthai S, Lim ST, Rawdkuen S. Optimization of microwave-assisted extraction of rice bran protein and its hydrolysates properties. J. Cereal Sci. 70:146-54 (2016).

F Fabian C, Ju YH. A review on rice bran protein: Its properties and extraction methods. Crit. Rev. Food Sci. Nutr. 51(9):816-27 (2011).

Milani J, Maleki G. Hydrocolloids in Food Industry, in Food Industrial Processes Methods and Equipment, ed. by Valdez B. In Tech, p. 17-38 (2012).

Rodríguez JM, Rodríguez MR, Carrera C. Implicaciones de las propiedades interfaciales en las características espumantes de proteínas lácteas, in Funcionalidad de Componentes Lácteos, ed. by Fontecha J, Recio I, Pilosof AM. CEE Limenc, España, p. 71-92 (2009). Porfiri MC, Vaccaro J, Stortz CA, Navarro DA, Wagner JR, Cabezas DM. Insoluble soybean polysaccharides: Obtaining and evaluation of their O/W emulsifying properties. Food Hydrocoll. 73:262-73 (2017).

21 Chuah AM, Kuroiwa T, Kobayashi I, Nakajima M. Effect of chitosan on the stability and properties of modified lecithin stabilized oil-in-water monodisperse emulsion prepared by microchannel emulsification. Food Hydrocoll. 23:600-10 (2009).

22 Esmaeili M, Rafe A, Shahidi SA, Hasan-Saraei AG. Functional properties of rice bran protein isolate at different pH levels. Cereal Chem. J.93(1):58-63 (2016).

23 Maldonado L, Latorre K, Rocha P, Medrano A, Abirached C, Panizzolo LA. Influencia del pH en la estabilidad de emulsiones elaboradas con proteínas de salvado de arroz. Rev Del Lab Tecnológico Del Uruguay, 6:28-31 (2011). Bera MB, Mukherjee RK. Solubility, emulsifying, and foaming properties of rice bran 
protein concentrates. J. Food Sci. 54(1):142-5 (1989).

25 Chandi GK, Sogi DS. Functional properties of rice bran protein concentrates. J. Food Eng. 79(2):592-7 (2007).

26 Devi E, Vijayendra SVN, Shamala TR. Biocatalysis and Agricultural Biotechnology Exploration of rice bran, an agro-industry residue, for the production of intra- and extracellular polymers by Sinorhizobium meliloti MTCC 100. Biocatal. Agric. Biotechnol. 1(1):80-4 (2012).

27 Association of Official Analytical Chemists. Official Methods of Analysis, 15th international edition. AOAC International, Gaithersburg, MD (1999). Wang C, Xu F, Li D, Zhang M. Physico-chemical and structural properties of four rice bran protein fractions based on the multiple solvent extraction method. Czech. J. Food Sci. 33(3):283-91 (2015).

29 López DN, Ingrassia R, Busti P, Bonino J, Delgado J, Wagner J, et al. Structural characterization of protein isolates obtained from chia (Salvia hispanica L.) seeds. $L W T$ Food Sci Technol. 90:396-402 (2018). Smith PK, Hermanson GT, Gartner FH, Frovenzano MD, Fujimoto EK, Goeke NM, et al. Measurement of protein using Bicinchoninic Acid. Anal Biochem.150:76-85 (1985).

31 Fernández-Fernández AM, López-Pedemonte T, Medrano-Fernandez A. Evaluation of antioxidant, antiglycant and ACE-Inhibitory activity in enzymatic hydrolysates of $\alpha$ Lactalbumin. Food Nutr. Sci. 8:84-98 (2017).

32 Cabezas DM, Madoery R, Diehl BWK, Tomás MC. Emulsifying properties of different modified sunflower lecithins. J. Am. Oil Chem. Soc. 89:355-61 (2012). Mengual O, Meunier G, Cayré I, Puech K, Snabre P. TURBISCAN MA 2000: multiple light scattering measurement for concentrated emulsion and suspension instability 
analysis. Talanta, 50(2):445-56 (1999).

34 Palazolo GG, Sorgentini DA, Wagner JR. Emulsifying properties and surface behavior of native and denatured whey soy proteins in comparison with other proteins. Creaming stability of oil-in-water emulsions. J. Am. Oil Chem. Soc. 81(7):625-32 (2004). emulsions of native and denatured whey soy proteins in comparison with soy protein isolates. Food Hydrocoll. 19:595-604 (2005). of rice bran protein isolates prepared with autoclaving and enzymatic hydrolysis. $J$. Korean Soc. Appl. Biol. Chem. 53(1):62-70 (2010). Fabian C, Ayucitra A, Ismadji S, Ju YH. Isolation and characterization of starch from defatted rice bran. J. Taiwan Inst. Chem. Eng.42(1):86-91 (2011).

38 Damodaran, S., Parkin, K. L. Fennema's food chemistry, 5 ed.; Damodaran, S., Parkin, K. L., Eds.; CRC Press. Boca Raton, Florida (2017). Moelbert S, Emberly E, Tang C. Correlation between sequence hydrophobicity and surface-exposure pattern of database proteins. Protein Sci.13(3):752-62 (2004).

40 Sorgentini DA, Wagner JR. Comparative study of foaming properties of whey and isolate soybean proteins. Food Res. Int. 35:721-9 (2002).

41 Thamnarathip P, Jangchud K, Jangchud A, Vardhanabhuti B. Functional properties of protein hydrolysates from Riceberry rice bran. Int. J. Food. Sci. Technol. 51(5):1110-9 (2016).

42 Alvarez MD, Canet W. Time-independent and time-dependent rheological characterization of vegetable-based infant purees. J. Food Eng. 114:449-64 (2013). Lizarraga MS, Piante Vicin D De, González R, Rubiolo A, Santiago LG. Rheological 
behaviour of whey protein concentrate and $\lambda$-carrageenan aqueous mixtures. Food Hydrocoll.20:740-8 (2006).

44 Rafe, A., Mousavi, SS., Shahidi, SA. Dynamic rheological behavior of rice bran protein (RBP): Effects of concentration and temperature. J. Cereal Sci. 60 (3):514-519 (2014).

45 Lindblad, MS., Albertsson, AC., Ranucci, E., Laus, M., Giani, E. Biodegradable polymers from renewable sources: Rheological characterization of hemicellulose-based hydrogels. Biomacromolecules 6 (2):684-690 (2005).

46 Leiva M, Geffroy E. Evolution of the size distribution of an emulsion under a simple shear flow. Fluids, 3(3):46 (2018).

47 McClements, D. J. Food emulsions : principles, practices, and techniques, CRC Press.; Boca Raton, Florida (2015).

48 Liu X, Guo J, Wan ZL, Liu YY, Ruan QJ, Yang XQ. Wheat gluten-stabilized high internal phase emulsions as mayonnaise replacers. Food Hydrocoll.77:168-75 (2018).

49 Dickinson, E. Hydrocolloids as emulsifiers and emulsion stabilizers. Food Hydrocoll. 23:1473-1482 (2009). 


\section{Figure and table captions}

Figure 1. Thermograms of defatted rice bran flour (DRBF) and concentrate (DRBC) aqueous dispersions (250 and $200 \mathrm{~g} \mathrm{~L}^{-1}$ in distilled water) obtained by differential scanning calorimetry.

Figure 2. Flow behavior of dispersions of defatted rice bran concentrates (DRBC) without (d) and with ultrasound treatment (ds) at $\mathrm{pH} 4.5$ and 7.0; A) shear stress as a function of shear rate (up and down curves, full and open symbols, respectively) and B) apparent viscosity as function of shear rate. The values are the mean of three independent determinations $(n=3)$.

Figure 3. Back scattering (\%BS) profiles and \%BS average values of initial and stored (28 days in quiescent conditions) of $\mathrm{O} / \mathrm{W}$ emulsions $\left(\phi_{\mathrm{m}}=0.25\right)$ obtained by mixing oil and aqueous dispersions without (eI, A and B) and with previous ultrasound treatment (eII, C and D) at pH 4.5 and 7.0. The \%BS average values were calculated in the lower zone of the tube $(10 \mathrm{~mm})$ and are the mean of three independent determinations $(n=3) \pm$ standard deviation.

Figure 4. De Brouckere, volume-weighted, mean diameters $\left(\mathrm{D}_{4,3}\right)$ of $\mathrm{O} / \mathrm{W}$ emulsions $\left(\phi_{\mathrm{m}}: 0.25\right)$ prepared by mixing oil and aqueous dispersions without (A) and with (B) previous ultrasound treatment at $\mathrm{pH} 4.5$ and 7.0. The values are the mean of three independent determinations $(n=$ 3) \pm standard deviation. Different letters between bars at the same storage time show significant differences $(\mathrm{P}<0.05)$ as determined by the Tukey Test. Different numbers within each emulsion show significant differences between the two storage times $(\mathrm{P}<0.05)$ as determined by the Tukey Test.

Figure 5. Frequency sweep tests, storage (G') and viscous modulus (G') as a function of the oscillation frequency $(0.1-20 \mathrm{~Hz})$ for $\mathrm{O} / \mathrm{W}$ emulsions $\left(\phi_{\mathrm{m}}: 0.25\right)$ prepared by mixing oil and aqueous dispersions without $(\boldsymbol{e I})$ and with (eII) previous ultrasound treatment, at $\mathrm{pH} 4.5$ and 
7.0. The nomenclature of emulsions was defined in the section 2.10. The values are the mean of three independent determinations $(n=3)$.

Table 1. Recovery yield ( $\mathrm{g} \mathrm{kg}^{-1}$ dry matter) and proximate composition ( $\mathrm{g} \mathrm{kg}^{-1}$ dry matter) of defatted rice bran flour (DRBF) and concentrate (DRBC).

Table 2. Protein solubility (PS), surface hydrophobicity $\left(\mathrm{H}_{0}\right)$ and $\zeta$-potential values of defatted rice bran flour (DRBF) and concentrate (DRBC). 


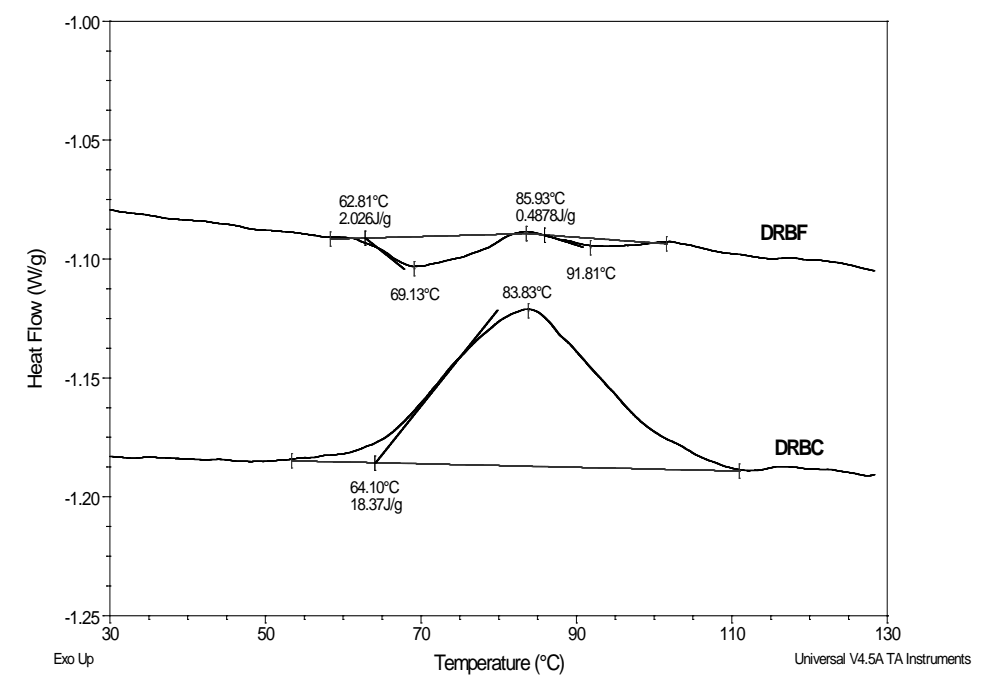

Figure 1. Thermograms of defatted rice bran flour (DRBF) and concentrate (DRBC) aqueous dispersions (250 and $200 \mathrm{~g} \mathrm{~L}^{-1}$ in distilled water) obtained by differential scanning calorimetry. 


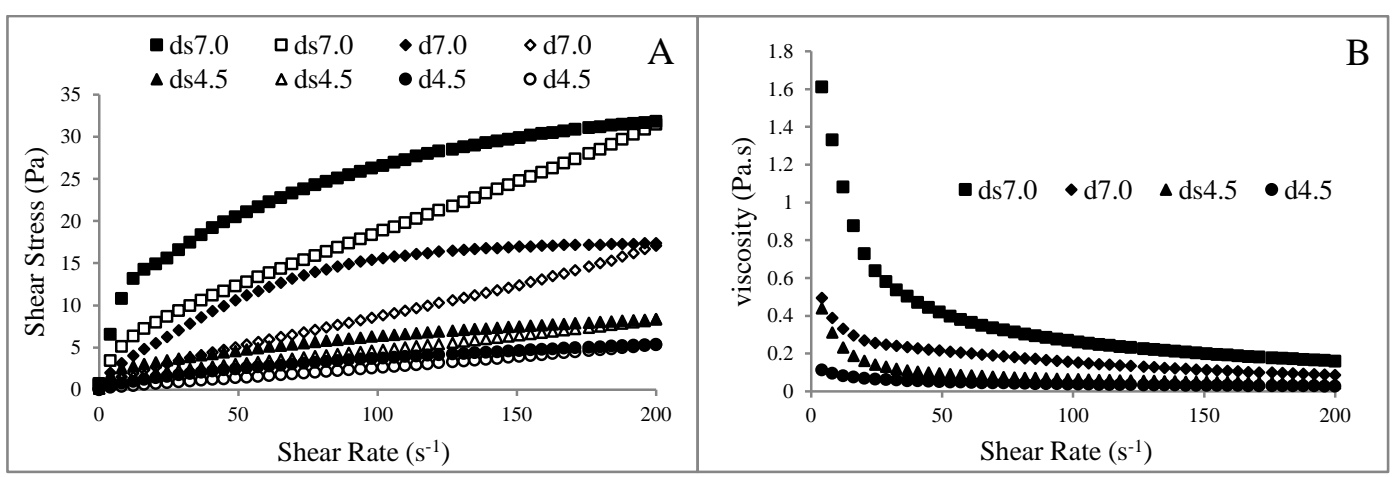

Figure 2. Flow behavior of dispersions of defatted rice bran concentrates (DRBC) without (d) and with ultrasound treatment (ds) at $\mathrm{pH} 4.5$ and 7.0; A) shear stress as a function of shear rate (up and down curves, full and open symbols, respectively) and B) apparent viscosity as function of shear rate. The values are the mean of three independent determinations $(n=3)$. 


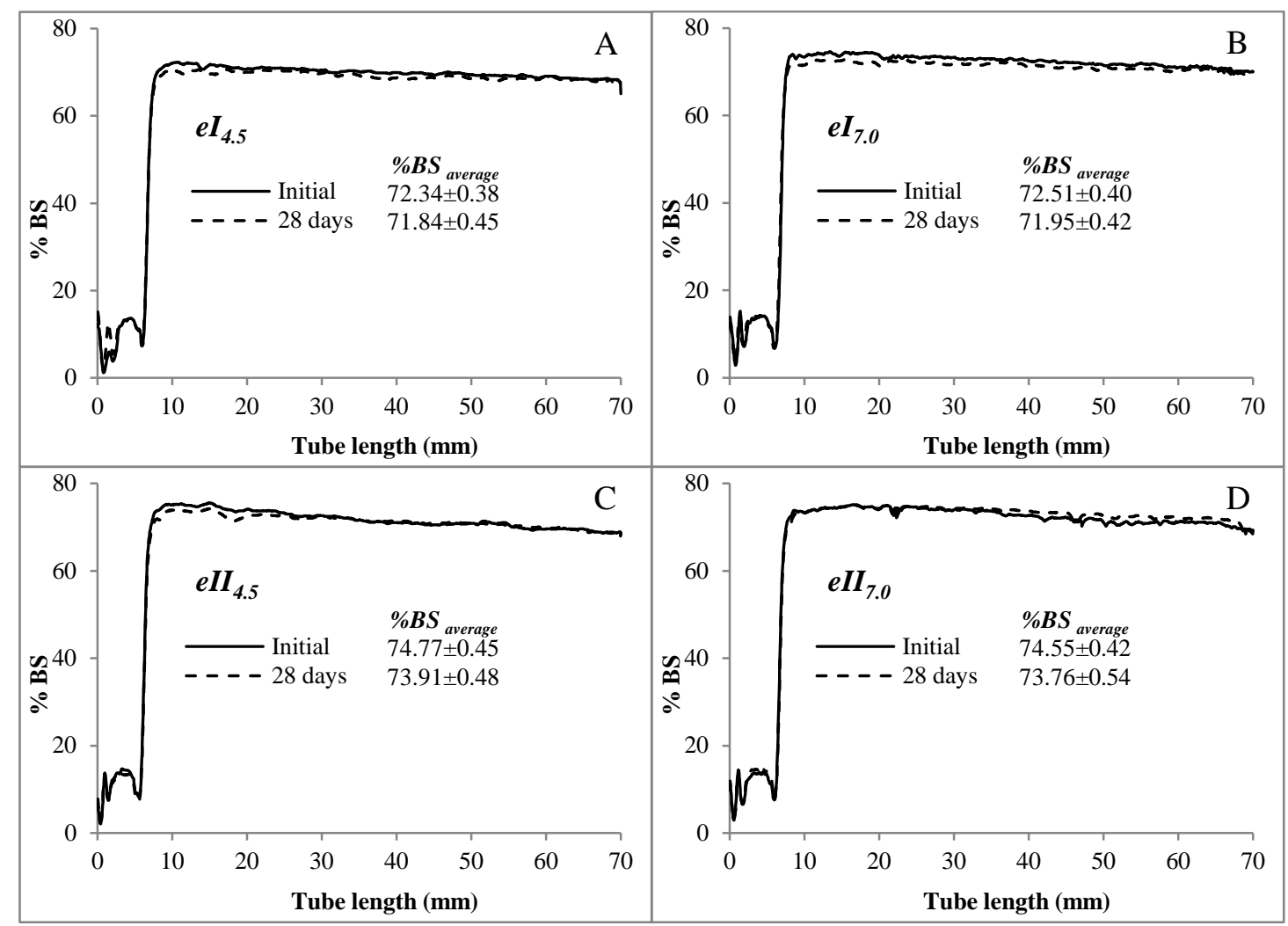

Figure 3. Back scattering (\%BS) profiles and \%BS average values of initial and stored (28 days in quiescent conditions) of $\mathrm{O} / \mathrm{W}$ emulsions $\left(\phi_{\mathrm{m}}=0.25\right)$ obtained by mixing oil and aqueous dispersions without (eI, A and B) and with previous ultrasound treatment (eII, C and D) at pH 4.5 and 7.0. The \%BS average values were calculated in the lower zone of the tube $(10 \mathrm{~mm})$ and are the mean of three independent determinations $(n=3) \pm$ standard deviation. 


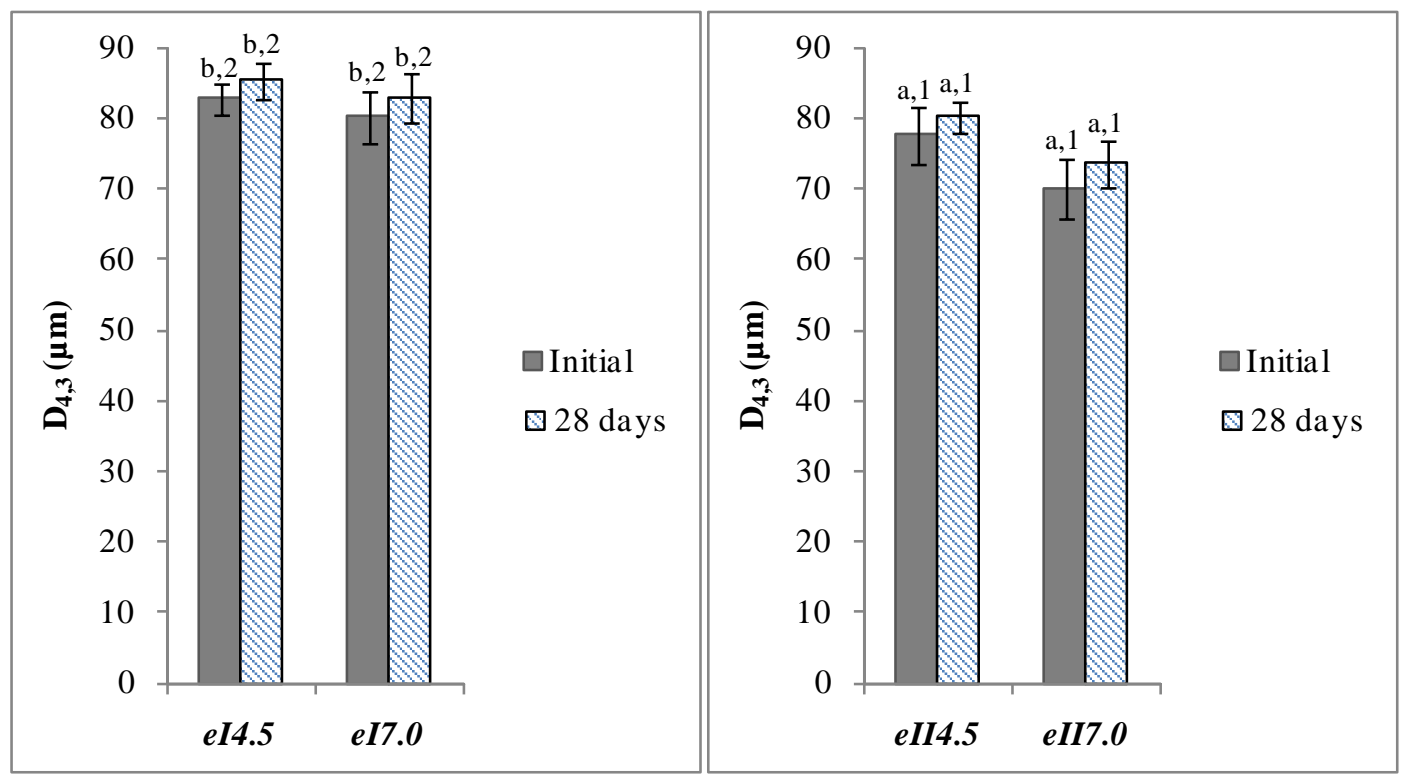

Figure 4. De Brouckere, volume-weighted, mean diameters $\left(\mathrm{D}_{4,3}\right)$ of $\mathrm{O} / \mathrm{W}$ emulsions $\left(\phi_{\mathrm{m}}: 0.25\right)$ prepared by mixing oil and aqueous dispersions without (A) and with (B) previous ultrasound treatment at $\mathrm{pH} 4.5$ and 7.0. The values are the mean of three independent determinations $(n=$ 3) \pm standard deviation. Different letters between bars at the same storage time show significant differences $(\mathrm{P}<0.05)$ as determined by the Tukey Test. Different numbers within each emulsion show significant differences between the two storage times $(\mathrm{P}<0.05)$, as determined by the Tukey test. 


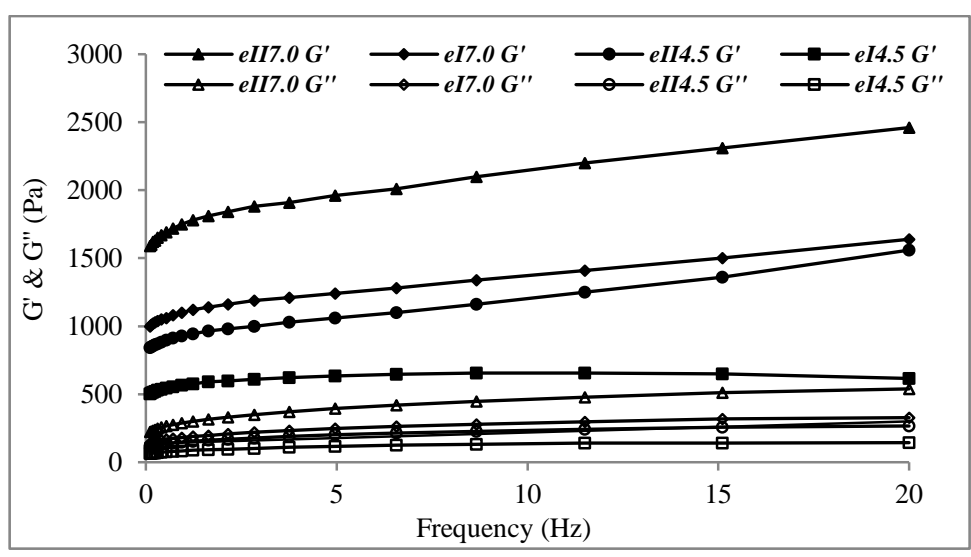

Figure 5. Frequency sweep tests, storage (G') and viscous modulus (G') as a function of the oscillation frequency $(0.1-20 \mathrm{~Hz})$ for $\mathrm{O} / \mathrm{W}$ emulsions $\left(\phi_{\mathrm{m}}: 0.25\right)$ prepared by mixing oil and aqueous dispersions without $(\boldsymbol{e I})$ and with $(\boldsymbol{e I I})$ previous ultrasound treatment, at $\mathrm{pH} 4.5$ and 7.0. The nomenclature of emulsions was defined in the section 2.10. The values are the mean of three independent determinations $(n=3)$. 
Table 1

\begin{tabular}{ccccccc}
\hline & Yield & Fat & Protein & Ash & Fiber & $\begin{array}{c}\text { Non-fiber } \\
\text { Carbohydrates } \\
*\end{array}$ \\
\cline { 2 - 7 } DRBF & - & $33.6 \pm 0.3^{\mathrm{a}}$ & $154.7 \pm 0.2^{\mathrm{a}}$ & $113.4 \pm 1.3^{\mathrm{a}}$ & $276.1 \pm 0.9^{\mathrm{a}}$ & $422.5 \pm 0.2^{\mathrm{b}}$ \\
DRBC & $560.9 \pm 27.0$ & $35.0 \pm 1.2^{\mathrm{a}}$ & $274.3 \pm 3.5^{\mathrm{b}}$ & $193.4 \pm 1.4^{\mathrm{b}}$ & $492.3 \pm 5.2^{\mathrm{b}}$ & $4.9 \pm 4.2^{\mathrm{a}}$ \\
\hline
\end{tabular}

Mean values $(n=3) \pm$ standard deviation with different letters in each column are significantly different $(\mathrm{P}<0.05)$, as determined by the Tukey test.

* Calculated by difference. 


\section{Table 2}

\begin{tabular}{ccccccc}
\hline & \multicolumn{2}{c}{ PS } & \multicolumn{2}{c}{$\mathbf{H}_{\mathbf{0}}$} & \multicolumn{2}{c}{$\zeta$-potential (mV) } \\
& $\mathbf{p H ~ 4 . 5}$ & $\mathbf{p H ~ 7 . 0}$ & $\mathbf{p H ~ 4 . 5}$ & $\mathbf{p H ~ 7 . 0}$ & $\mathbf{p H ~ 4 . 5}$ & $\mathbf{p H ~ 7 . 0}$ \\
\hline DRBF & $355 \pm 7^{\mathrm{b}, 1}$ & $345 \pm 6^{\mathrm{b}, 1}$ & $14,444 \pm 208^{\mathrm{a}, 1}$ & $15,650 \pm 592^{\mathrm{a}, 2}$ & $-44.0 \pm 1.0^{\mathrm{a}, 1}$ & $-44.8 \pm 0.1^{\mathrm{a}, 1}$ \\
DRBC & $102 \pm 1^{\mathrm{a}, 2}$ & $91 \pm 6^{\mathrm{a}, 1}$ & $18,891 \pm 140^{\mathrm{b}, 1}$ & $21,235 \pm 1,103^{\mathrm{b}, 2}$ & $-58.3 \pm 0.4^{\mathrm{b}, 1}$ & $-70.1 \pm 1.6^{\mathrm{b}, 2}$ \\
\hline
\end{tabular}

Mean values $(n=3) \pm$ standard deviation with different letters in each column are significantly different $(\mathrm{P}<0.05)$, as determined by the Tukey test. Mean values $(n=3) \pm$ standard deviation with different numbers in rows are significantly different $(\mathrm{P}<0.05)$, as determined by the Tukey test. PS calculated as gram of soluble protein per kg of the total protein. 